\title{
FLOUTING MAXIMS IN CREATING HUMOR: A COMPARISON STUDY BETWEEN INDONESIAN AND AMERICAN STAND UP COMEDY
}

\author{
${ }^{\text {a }}$ Maulidya Ayu Puspasari, ${ }^{\mathrm{b}}$ Lisetyo Ariyanti \\ ${ }^{\mathrm{a}, \mathrm{b}}$ English Literature - Universitas Negeri Surabaya \\ e-mail: lisetyoariyanti@unesa.ac.id
}

\begin{abstract}
In a stand up comedy, the Stand-up comedian or also known as comic have to tell about their restlessness to the audience in a funny way. In order to make the audience laugh, they surely need to make the audience understand the topic being discussed. Concerning to the success of a communication, Paul Grice (19890 proposed four cooperative principles that people expected to follow; maxim of quantity, maxim of quality, maxim of relevance, and maxim of manner (Yule, 1996). However, Attardo claims that disobeying maxims is common in a research of humor (Attardo, 1990). Thus, this study is purposed to compare the flout of maxims done by an Indonesian comic and an American comic, its joke techniques which they employ while flouting maxims to create humorous materials and the reason why they flout certain maxim the most and use certain joke techniques. This study uses descriptive qualitative method to observe the result of flouting maxims in Stand up comedy. The result finding of this study will be in a form of descriptive text. The participants of this study are an Indonesian comic named Abdur Arsyad and an American comic named Kevin Hart. The result of this study finds that the maxims each comics flout the most are different which is influenced by the difference of their nationalities and cultures. Kevin flouts maxim of quantity the most because of the influence of American culture which tend to be direct in communication. Meanwhile, Abdur flouts maxim of quality the most because of the influence of Indonesian culture which tend to be indirect in communication. Even though the maxim they flout the most are different, their flout of maxims are similarly employed all types of joke techniques which contributed to create humor. Their flouts of maxims have employed paralanguage, ridicule, satire, and politeness strategy of joke techniques. The similarity of the joke techniques employed by both comics is influenced by their ethnic background. Abdur Arsyad and Kevin Hart have different nationalities, however they have the same ethnic background. Abdur comes from East side of Indonesia, and Kevin is AfricanAmerican which both are minority in their countries. Therefore, they employ the same joke telling technique to deliver the jokes. It can also be influenced by their joke materials which are similar. Both of them usually bring up the topic of the restlessness of being minority and about social criticism.
\end{abstract}

Keywords: Cooperative principle, Flouting, Stand-up Comedy. 


\section{INTRODUCTION}

Recently, there is a new kind of comedy which is popular in Indonesia, stand-up comedy. This kind of comedy can be performed by one person or in a group of people. The stand up comedian or also known as comic will stand up on stage to tell jokes live directly to the audiences. In a stand up comedy, the comic have to tell about their restlessness to the audience in a funny way. Even though stand up comedy is using monologue kind of story-telling, but the comic still need to make sure the audience catch on with the topic being discussed. Concerning to the success of a communication, Paul Grice proposed four cooperative principles that people need to follow. They are maxim of quantity, maxim of quality, maxim of relevance, and maxim of manner. If the audience do not understand what the speakers are saying, the audience may not be able to laugh at the joke that the speakers deliver. Thus, the cooperative principles are expected to follow in stand up comedy performance. However, according to Attardo, it is common in a research of humor which claims that every jokes will at least violate one maxim of the cooperative principle (Attardo, 1990).

In some of the previous studies, the research in maxims violations done by comic is often being examined, mostly the subject is from one particular comic in one country, Indonesia. In this study, there are two comics who will be observed. First, is a comic from America named Kevin Hart. Kevin Hart is usually talking about his race, his physical as well as his personal life as the materials to create humor. Then, this study also observes a comic from Indonesia named Abdur Arsyad. Similar with Kevin Hart, he also mostly uses his race as an East Indonesian as the material of his joke. This study compares the flout of maxims of two comic from two different countries, Indonesia and the origin country of stand up comedy, America. It is interesting to analyze whether comic who often use the same joke content about race will flout maxims differently to create humorous effect and whether they will employ different joke techniques which is triggered by their flout of maxims or not and what is the reason behind the flout and the use of joke technique each comic employ. Therefore, this study tries to reveal: 1) What kind of maxims does each American and Indonesian stand up comedian flout the most? 2) How do the characteristics of joke techniques which contributed by flouting maxims in those two countries? 3) Why does each comedian flout certain maxim the most and use certain joke technique?

\section{LITERATURE REVIEW}

\section{Flouting Maxims}

Flouting maxims is happened when someone intentionally disobey the maxims principle in the hope that the listener will get the hidden meaning that is conveyed implicitly through the speaker utterances (Jorfi \& Dowlatabadi, 2015). It is in line with Thomas statement which says that flouting maxims is the interlocutor choice to ignore maxim principle by using conversational implicature to add the meaning which is beyond the literal meaning of the utterance. The purpose of flouting maxim is to make the audience catch the hidden meaning that the speaker tries to convey as cited in (Andresen, 2013). The reason why the researcher uses flouting maxims theory is because according to Attardo, disobeying maxims can create humorous effect (Attardo, 1990).

a. Flouting Maxim of Quantity happens when a speaker gives information more or less than it is needed. 
b. Flouting Maxim of Quality happens when the speaker says something that is false and lack of evidence.

c. Flouting Maxim of Relevance happens when a speaker says something or gives response which is irrelevant to the topic being discussed.

d. Flouting Maxim of Manner happens when the speaker is not being brief or not to the point, using vague language, and being ambiguous. The flouts create implicatures which make the hearer seek for additional meanings being implied through the utterances.

\section{Humor}

Stand-up comedy is a comedy show which definitely related and must be contained of humor. That is why the researcher includes humor theory in her research, it is because of the word comedy itself means "humorous part of a situation" according to Cambridge dictionary. Humor is a quality that makes something funny. It has the ability to make people laugh because of its amusement (Oxford Advanced Learner's English Dictionary, Sixth edition, p 863). Humor is any kind of things which are intentionally made to trigger laughter (Audrieth, 1998:3-4). It is something that attracts people interests with funny words and or body languages to arouse laughter. Humor mostly occurs in daily conversation (Pan, 2012).

\section{Joke Technique}

In her research, Schwarz mentions four linguistic features that are common to be found in stand up comedy performance (Schwarz, 2010). These four linguistic features will be used also in this research to study the joke telling performance done by Abdur Arsyad and Kevin Hart which is in line with their strategy of creating humor by flouting maxims.

a. Paralanguage is a type of verbal humor including body language and intonation. Schwarz argues that paralanguage is one of joke techniques which has an essential role in comedy and a crucial characteristic in stand up comedy (Schwarz, 2010). The quality of the comics' performance does not only lie to the content of the jokes they tell, but their stage persona and manner of presenting the joke also contribute to the performance's succeed. Therefore, paralanguage or nonverbal humor is essential to the successful of comedians' performances in delivering their jokes.

b. Ridicule is a joke technique which used an insult or mockery to create laughter. According to Berger as cited in Schwarz (2010), ridicule is defined as "a form of direct verbal attack against a person, thing, or idea." It displays impoliteness and aggressiveness which aims is to attacks others by presenting them as ridiculous. Ridicule is distinguished into three; private ridicule, shared-ridicule and self-ridicule (Wilson 1979: 189/190 as cited in Schwarz (2010). Private ridicule is primarily used to mock racial and cultural minorities which is directed to real people. Shared ridicule is happened when the comedians ridicule themselves and their own audiences at the same time. Meanwhile selfridicule happens when the comedians ridicule themselves.

c. Satire is a subcategory of ridicule which used to make fun of people whom the speaker thinks is superior. Berger argues that satire used to ridicule specific person, institution, or event. According to Koestler as cited in Schwarz (2010), satire is defines as "verbal caricature which distorts characteristic features of an individual or society by exaggeration and simplification". Moreover, the aim of satire is to improve an individual, thing, or idea by ridiculing their 
shortcomings or mistakes. In a humor, instead of just to arouse laughter, satire makes people think and make improvements.

d. Power, Solidarity, and Politeness Strategies can create humorous materials. Schwarz states that power has an essential role for creating hostility and release theory. The other scientists such as Plato, Aristotle, and Hobbes state that laughter can be triggered by superiority occurred because of power. Solidarity is also contributed to humor strategy because humor helps soften the seriousness of a condition as well as express the feeling of solidarity itself. In stand up comedy, positive politeness strategies including hedges, hesitation markers, question tags, or modal verbs are frequently occurred. The comics use it to connect or build up connection with the audience and express solidarity by using indirect speech to avoid being rude in forcing the audience into their point of views. In humor, power and authority do not have to be conveyed by using direct speech acts only, but it can be expressed implicitly through the use of sarcasm and satire.

\section{Stand Up Comedy}

Stand up comedy is a comedy style which is performed on stage by a comedian who tell jokes directly to the audience (Yamazaki, 2010). There are some differences of opinion about when was the establishment of stand up comedy in the world began. Jim Mendrinos, a comedian said in The History of Comedy: The First Stand Up, that the term stand up comedy has been introduced since 1960s. While comedian Lenny Bruce, said that Stand Up Comedy has existed since 1950's. Originally, stand up comedy in American was done on theater. Back in America, there was a theater called The Minstrel Show which was considered as the beginning of the eruption of stand up comedy world which was held by Thomas Dartmouth.

\section{METHOD}

The aims of this study are to investigate what types of maxims each comic flout the most, how do their flout of maxims contribute to joke technique to create humor, and the reason why each comedian flout certain maxim the most and use certain joke technique. Thus, descriptive qualitative method was suitable for this study to observe the result of flouting maxims in Stand-Up Comedy which is done by an American (Kevin Hart) and an Indonesian (Abdur Arsyad) comic. The result findings of this study were in a form of descriptive text. Qualitative research is a research employed by exploring and understanding individuals or groups meaning deals with a social or human problem. The result of qualitative research is usually in a form of word and not in a form of number (Creswell, 2009). The data of this study are the utterances of both comics which taken from their stand up video performances uploaded on Youtube.

In this study, documents and materials culture were analyzed. The use of documentative method often requires a special analytical approach called content analysis. The data for content analysis can be in any form of communication including written and spoken. This method can be used to describe and interpret the facts of a society. In order to analyze the data collection, the data were transcribed and translated (Marshall, 2006). According to Fraenkel and Wallen in Creswell (2009:195), the one who conducts a research is the main instrument in data collection. Since the one who described and interpret the data is the writer itself, so, an observation of both stand up comedian video performances were based on a note field or table containing of the characteristic of maxims and joke technique theory were the instrument of this study. 
Moreover, the collected data which were taken by downloading the video on YouTube were transcribed and printed to ease the data analysis.

There were some steps used to get the results from the videos in this study. It consist of; downloading videos performance from YouTube, watching the video performance, making transcript of the video, listing transcript, and identifying the result with related theories. The next step that the researcher should take after collecting data is analyzing the data. There are three points which need to be included in data analysis technique in order to provide good analysis of the data; data condensation, data display, and conclusion, drawing, and verification (Miles, Huberman, \& Saldana, 2014).

\section{RESULT}

\section{Abdur Arsyad}

The data presented below are some of the examples of the utterances which are taken from Abdur performances on Stand Up Comedy Kompas TV Show 4 and 8 which are uploaded on Youtube by Stand Up Kompas TV. The data are the utterances from two of Abdur Arsyad video performances during his stand up competition in Stand up Comedy Show Kompas TV on 2014. The data of this research are presented in the form of descriptive. The data which has been categorized as flouting maxims will be translated to English.

\section{Data 1}

Ketika seтua yang disini itu sudah bersistem dengan online, di tempat saya itu aduuuh..oh lain (When everything has been online-based now, in my place is oh gosh...oh-different)

\section{Analysis}

The speaker flouts maxim of quantity by giving information more than needed. $\mathrm{He}$ explains about how everything is online system based. Then, he adds additional information that in his hometown, there is no online based system, but "oh lain" which means different. He plays with the word online to be "oh lain" which creates incongruity types of humor. It is because of the surprise effect he gave through the way he play with the word "online" and change it into oh-different. He employs satire technique of joke by ridiculing the system or condition of his hometown. The word "oh-different" refers to the remote area of his hometown in an exaggerating way. Instead of saying that his hometown hasn't applied online-based system yet, he mentions his hometown condition as "oh-different" to imply how undeveloped his hometown is so that it is as if his hometown is in different world. Also, through his utterance, the speaker expresses his protest possibly toward the government because his hometown in East Indonesia has not developed yet. Thus, he aims to make the government to develop his hometown.

\section{Data 2}

Eh, itu yang dipojok yang di bawah pohon beringin itu kalian masuk saja kalian kan sudah biasa nepotisme (Hey, the one who are under the banyan tree, you can just come in, you get used to nepotism right)

\section{Analysis}

The speaker flouts maxim of quality by saying something lack of evidence to implicitly express his protest about nepotism that possibly happened in Indonesia regarding with specific institution or organization related to Banyan Tree. It creates 
incongruity types of humor because the audience does not expect him to quip political party. He employs satire technique of joke by implicitly mock an institution. He satirizes certain political party by mentioning "people under banyan tree" which refer to one of political party in Indonesia which symbol is banyan tree. He aims to make that political party to improve their human resources so that nepotisms in that political party will not exist ever again.

\section{Data 3}

Beliau kalau sudah nonton sinetron, itu semua penghuni rumah itu wajib diam dan tenang. Hukumnya itu fardhu ain. (When she watches TV series, all people at home must be quiet. It is fardhu ain)

\section{Analysis}

The speaker flouts maxim of quality by stating something that is not true. He states that being quite while his mother watches TV series is a must. He even mentions that is Fardhu Ain to be quiet. Fardhu Ain is a law or rule in Islam which must be followed and obeyed by Moslem. However, there is never been any rule which mentions that people need to be quiet when watching TV series. Thus, the speaker is stating lies. The speaker lies to implicitly show his mother superiority and to mock his mother by showing how scary she could be. Thus, he employs satire joke technique which creates incongruity humor because the audience does not expect his mother would be that scary.

\section{Data 4}

Mereka itu sampai larang anak-laki-lakinya kami untuk main di panas, karena mereka bilang takut hitam. Aduh mama sayange (They prohibit their son to go out under the sunlight because they are afraid they will get dark complexion. Oh my goodness)

\section{Analysis}

The speaker flouts maxim of manner by using slang words. The speaker uses vague languages to show his disbelief on how can an East people who are born with dark complexion are afraid to get dark complexion. His utterance when saying "oh my goodness" also implicitly mock East people who are afraid to get dark complexion. Thus, he employs satire technique of joke which creates incongruity humor by giving the surprise effect to the audience through his choice of word. He employs satire technique of joke because when he mocks the idea of East people fear of dark complexion, he actually wants those people not to have that fear anymore, because the idea of being scared to get dark complexion is stupid for him since they are born with it.

\section{Data 5}

Saya bersyukur sekali saya bisa kuliah di Malang, paling tidak saya tahu bagaimana cara naik lift (I'm very grateful I can study in Malang, at least I know how to use an elevator)

Analysis

The speaker flouts maxim of relevance by stating something that is irrelevance to the previous topic. Previously, he says that he feels lucky to be able studying in Malang. After that, he continues saying that "at least he knows how to take an elevator". The speaker is being irrelevance to implicitly mock himself for feeling lucky just because he could use an elevator and to implicitly define the non modern condition of his hometown. Thus, he employs ridicule technique which creates incongruity humor because the audience will assume that his next utterance would be related to academic things. 


\section{Kevin Hart}

The data presented below are some of the examples of the utterances which are taken from two of Kevin Hart video performances on Saturday Night Live on 2013 and slice part of his performance in his show called Seriously Funnyon 2010.

\section{Data 6}

We was watching SpongeBob. Right? Something happened to Patrick. Out of nowhere, she got mad.

She's like "Shit".

I said, "Wait. What? What'd you say?"

\section{Analysis}

The speaker flouts maxim of quantity by giving less information than needed. The speaker should have give further information before or after he curses while imitating his daughter. He could have said that his daughter got so upset because something happened to Patrick which possibly her favorite character, thus she got so upset that she cursed. However, instead of giving enough information or explanation, he only curses. Through his flouting, it can be implied that he wants to convey his concern about how the kid nowadays are not as innocent as they can curse when they watch cartoon. He employs positive politeness by using swearing words when he was imitating his daughter when she cursed while watching SpongeBob. The use of positive politeness is used to show the close relationship between those two that his daughter does not even hesitate to curse in front of his father. Also, it is also possible that the speaker uses swearing words because he has know the audience well so that he thinks it is okay to use curse words. His utterance creates incongruity humor because the audience do not expect that his little daughter would curse since she was a still a kid and it was happened when she watched SpongeBob which is a cartoon movie.

\section{Data 7}

"You gonna smack me, bitch? (Shrieking) In front of my friends? You're gonna smack me in front of my friends?!

\section{Analysis}

The speaker flouts maxim of quantity by repeating the same sentences. He flouts maxim of quantity when he is telling about the situation when his friends are visiting his house and then they play together and being loud. Then, his mother scolds him for being loud and smacks him in front of his friends. The words "You're gonna smack me in front of my friends? " are repeated to implicitly show his disbelief and his feeling. It is as if to show that his mother has hurt his pride by smacking him in front of his friend. He raises his intonation while he says that words, thus, he employs paralanguage technique of joke. It creates incongruity humor because the audience does not expect that he will behave that way after getting smacked by his mother.

\section{Data 8}

She ain't have no nipples

\section{Analysis}

The speaker flouts maxim of quality by saying something lack of evidence. He said that his teacher does not have nipples. He does not provide evidence to proof that his teacher does not have nipples. Also, his statement can be considered as a lie because his teacher is a woman, thus she must have born with it. The speaker is flouting 
maxim of quality possibly to imply that maybe his teacher body figure is not womanlike for him so that it is as if she does not have nipples. Also, his flouting is used to show his hatred toward his teacher by mocking her body figure. He employs ridicule joke technique because he aims to embarrass his teacher by insulting her body figure. Moreover, his mocking has created incongruity humor due to the surprise effect it gives to the audience. It is because the audience does not assume he will say that his teacher does not have nipples because she is a woman. Also, the audience does not expect him to be brave enough to mock his teacher who should have been respected.

\section{Data 9}

I'm gonna go to bed early and get some rest 'cause I got a big day ahead of me tomorrow (Audience laugh) I don't want to really mess this up.

\section{Analysis}

The speaker flouts maxim of manner by being ambiguous. He says that he is going to go to bed early and get some rest because he got a "big day" tomorrow. The use of the word "big day" is ambiguous, because he does not explain what big day means. However, it can create laughter because the audience still understands what he means. The word "Big Day" refers to the day when he is ordered by his mother to tell her teacher to mind her own business. It creates laughter because he refers the day as a "Big Day" to indicate that it is a day that he's been waiting for. The speaker is being ambiguous to show his excitement to the day when he got the permission to cuss his teacher. The speaker employs paralanguage joke technique because he raises his intonation to emphasize the word "Big Day". In addition, it creates incongruity type of humor because the audience do not assume that he will refer the day when he is going to scold his teacher as a big day which is usually refers to a happy day or an exciting day.

\section{Data 10}

A homeless guy's hands flicking your lip. Let me tell you something, that's just like an outbreak monkey touching your lip

\section{Analysis}

The speaker flouts maxim of relevance by comparing two unrelated things. He says that if a homeless guy flicking your lips is like an outbreak monkey touching your lips. A homeless guy and outbreak monkey do not have any relation with one another. However, the speaker says that to implicitly express his thought about how he thinks that a homeless guy is like an outbreak monkey who are neglected and not maintained well like unkempt person. When he utters the words, the speaker employs ridicule technique of joke by mocking the homeless guy and compares it with an outbreak monkey. It creates hostility types of humor because it makes the audience laugh at the homeless guy weakness regarding to his hygiene.

Data presented below are some of the examples of flouting maxims done by Indonesian and American stand up comedian. From the data analysis above, it can be concluded that both comics are flouting all types of cooperative principles in their performances in order to create humorous materials. More examples of data analysis can be seen in appendix. The total of flouting maxims done by both comic will be summarized into data display below in a form of table to show what maxims each comic flout the most and the frequent of joke techniques employed through their flouts of maxims to create humor. 
Table 1. Flouting Maxims

\begin{tabular}{|c|c|c|c|c|}
\hline \multirow[b]{2}{*}{ Maxims } & \multicolumn{2}{|c|}{ Abdur Arsyad } & \multicolumn{2}{|c|}{ Kevin Hart } \\
\hline & (SUCI 4 Show 4) & (SUCI 4 Show 8) & $\begin{array}{c}\text { Seriously Funny - } \\
\text { Swearing at My } \\
\text { Teacher }\end{array}$ & $\begin{array}{c}\text { Kevin Hart } \\
\text { Monologue - } \\
\text { SNL }\end{array}$ \\
\hline Quantity & 2 & 4 & 5 & 3 \\
\hline Quality & 2 & 5 & 2 & 4 \\
\hline Manner & 3 & 2 & 3 & 4 \\
\hline Relevance & 3 & 3 & 0 & 1 \\
\hline Total & $\begin{array}{l}\text { - Quantity : } 6 \\
\text { - Quality : } 7 \\
\text { - Manner : } 5 \\
\text { - Relevance : } 6\end{array}$ & & $\begin{array}{l}\text { - Quantity : } 8 \\
\text { - Quality : } 6 \\
\text { - Manner : } 7 \\
\text { - Relevance : } 1\end{array}$ & \\
\hline
\end{tabular}

Table 2. Joke Technique

\begin{tabular}{|l|c|c|c|c|}
\hline \multirow{2}{*}{ Maxims } & \multicolumn{2}{|c|}{ Abdur Arsyad } & \multicolumn{2}{c|}{ Kevin Hart } \\
\cline { 2 - 5 } & (SUCI 4 Show 4) & (SUCI 4 Show 8) & $\begin{array}{c}\text { Seriously Funny - } \\
\text { Swearing at My } \\
\text { Teacher }\end{array}$ & $\begin{array}{c}\text { Kevin Hart } \\
\text { Monologue - } \\
\text { SNL }\end{array}$ \\
\hline Paralanguage & 1 & 1 & 2 & 0 \\
\hline Ridicule & 3 & 6 & 3 & 4 \\
\hline Satire & 3 & 5 & 0 & 2 \\
\hline $\begin{array}{l}\text { Politeness } \\
\text { Strategy }\end{array}$ & 2 & 1 & 2 & 1 \\
\hline
\end{tabular}

\section{DISCUSSION}

\section{The Most Flouted Maxim}

Based on the display analysis in 4.1 and 4.2, it can be concluded that the result of research question number one in this study about what maxims do each comics flout the most are different. Even though both comics flout all types of maxims in their performances, however the maxims which they flout the most are different to one another. In the performances of an Indonesian comic named Abdur Arsyad, he flouts maxim of quality the most. The example is in data number two which says "Hey, the one who are under the banyan tree, you can just come in, you get used to nepotism right". It is shown that he flouts maxim of quality by stating something that lack of evidence, he accuses someone with nepotism case without giving any proof of his statement. It flouts maxim of quality because according to the theory of maxim quality by Paul Grice as cited in Yule (1996), people need to be truthful at giving information and provides evidence to their statement. However, it can create humor because his flouting contributes to joke technique called satire. It is because there is a hidden message that he wants to convey by flouting the maxim and he mocks certain institution through his flouting. It is in line with what Berger says that satire is used to ridicule specific institution as cited in Schwarz (2010). In Abdur utterances, he mentions that people under banyan tree get used to nepotism. The words "banyan tree" can refer to one of the political party in Indonesia which has symbol of banyan tree. By mentioning people under banyan tree, the speaker might be implicitly protested to that institution which he thinks do nepotism. It is also possible that the audience laugh along because they know about that case. In addition, his utterance is creating incongruity types of humor due to the surprise effect it gives to the audience which is in line with theory of humor by Raskin as cited in Schwarz (2010). It is because the audience does not expect him to mock specific political party. 
On the other hand, an American comic named Kevin Hart flouts maxim of quantity the most. One of the examples is presented in datum number six in 4.2. He flouts maxim of quantity when he imitates his daughter when she watches SpongeBob. Out of sudden he curses, he says "shit" without adding more information. It flouts maxim of quantity because it does not follow the theory of maxim of quantity which requires people to be informative by Paul Grice as cited in (Yule, 1996). When Kevin flouts maxim of quantity, he employs joke technique called positive politeness by using swearing words. Positive politeness usually used to show solidarity, the speaker employs positive politeness to develop positive relationship or build connection with the audience in order to soften the seriousness of the situation. It is in line with Mills statement about positive politeness strategy which usually used to develop positive relationship with other and its characteristic such as the use of slang, swearing words, and making compliment as cited in (Schwarz, 2010). Kevin utterance also creates one of the types of humor theory called incongruity. It is because the one who curses is his daughter, and it surprises the audience because how could a kid curse when she was watching cartoon. It is in line with the theory of humor types by Raskin as cited in Schwarz (2010) which says that incongruity is happened when there is a surprise effect which triggered laughter. Through his flouting, Kevin probably intends to convey his concern about how the kids nowadays are not as innocent as they can curse when they watch cartoon, which is ironic.

\section{Characteristic of Joke Techniques which are Employed}

Similar to one another, their utterances which flout maxims also employing joke techniques which contribute to create humor. The flout of maxims which have done by both stand up comedian from Indonesia and America are proven to contribute to all types of joke technique theory by Jeannine Schwarz (2010) in order to create humor. Through the flout of maxims which have been done by Abdur, it is concluded that he has applied all types of joke techniques including paralanguage, ridicule, satire, and politeness strategy. The total amount of paralanguage technique that is employed is 2 , ridicule 9 , satire 8 , and 1 politeness strategy and 1 negative politeness strategy. Two of paralanguage techniques that he employed through flouting cooperative principle have created hostility and incongruity types of humor. Nine of ridicule techniques that he employed have created incongruity and hostility types of humor. Then, eight of his satire techniques of joke have created incongruity, hostility and release theory of humor. As for positive politeness strategy technique of joke that he employed, he managed to create hostility type of humor and incongruity types of humor for negative politeness strategy. Among those four types of joke techniques, ridicule is the most used joke technique that he employed to create humor. In his performances, he uses ridicule as a way to mock or criticize. It is in line with Maman Lesmana's research about The Aspect of Ridicule in Indonesian Humor. It is mentioned that there are two functions of ridicule; to criticize, and to entertain (Lesmana, 2017).

Similar with Abdur Arsyad, an American comic named Kevin Hart also employs all types of joke technique by Schwarz (2010). The joke techniques that he employs through his flouting are paralanguage 2 , ridicule 7 , satire 2 and positive politeness strategy 3. Paralanguage technique of joke which he employed through flouting maxim has created incongruity types of humor. Next, his technique of ridicule by flouting maxim has created incongruity and hostility types of humor. Satire joke technique that he employs has created release type of humor. Then, his politeness strategy of joke technique has created incongruity type of humor. All the joke techniques that he 
employs through his flouting maxims are in line with the characteristic of American humor article published by Columbia West College website entitle Understanding American Jokes. In the article, it is mentioned that American jokes usually consist of slapstick, insult comedy and impersonations, satire, and observational humor. Slapstick comedy related to physical comedy which is the same with paralanguage joke technique which related to intonation and gesture (Schwarz, 2010). Next, is insult comedy which is similar with ridicule joke technique mentioned in Schwarz's dissertation. Impersonation also used in the joke material that Kevin used to create humor which is also related with paralanguage technique of joke because it is related with intonation and gesture. The last type is satire joke which uses sarcasm, puns, and situational irony to arouse laughter.

\section{The Reason Behind The Use of The Most Flouted Maxim and Certain Joke Technique}

In this study, the researcher finds that in order to create humorous materials, there are some similarities that both comic have related with flouting maxims. The first similarity is the types of maxim they have flouted. They are similarly flouting all types of maxims including maxim of quantity, quality, manner, and relevance in their performances. Indonesian comic named Abdur Arsyad has flouted all cooperative principles theory with a total of 24 flouts consisting 6 flouts of maxim quantity, 7 flouts of maxim quality, 5 flouts of maxim manner, and a total of 6 flouts of maxim relevance. An American comic named Kevin Hart flouts a total of 8 maxim of quantity, a total of 6 flouts of maxim manner, then 7 flouts of maxim quality, and 1 flouts of maxim relevance. The total amount of flouting maxim done by Kevin Hart is 22. The difference between the two comics is the frequency of what maxims do they flout the most. This is happened because they have different background cultures. It is supported by Nina Setyaningsih's study which finds that jokes delivered by comedians are influenced by their ethnic background (Setyaningsih, n.d.). The result of this study finds that in order to create humorous materials, an American comic flouts maxim of quantity the most. Meanwhile, an Indonesian comic flouts maxim of quality the most to arouse laughter. An Indonesian comic named Abdur Arsyad is flouting maxim of quality the most. It is in line with Indonesian culture which prefers to be indirect. They tend to be indirect when criticizing people or stating his argument which might be different from other. That culture sometimes makes them considered as being dishonest or hypocritical by westerners. It is also supported by Servaes statement which says Asian people are indirect and implicit in communication (Kakabadse, 2007). Therefore, an Indonesian comic named Abdur, one of the subjects of this study flouts maxim of quality the most as a way to satirize certain people, institution and condition of his hometown. It can be seen through the data number 2 and 3 in 4.1 about how he uses satiric words to mock certain people and institution.

On the other hand, an American comic named Kevin Hart flouts maxim of quantity the most in his performances. The reason behind this can be because of his nationality as an American which has a culture of being direct in a conversation. They often be assertive about what they want. Being assertive is generally seen as a good thing in America. In conversation, if Americans disagree with your point of view or opinion, they will tell you directly, even when it is with their teachers because they believe in freedom of speech. According to Bryant, Sue (2018), Chinese people even considered Americans as rude in conversations because they are really direct and straightforward at expressing their thoughts. It is because social hierarchy does not 
really important in America and they value equality. Meanwhile, Chinese people tend to avoid confrontation with a view to saving face while Americans prefer to be frank because they think the result is more important than reputation and relationship. It is also supported by the statement made by Servaes that Westerners are direct and explicit (Kakabadse, 2007). In some of data presented in 4.2, it shows how direct Kevin Hart at expressing his thought. In data number 6, his daughter is cursing without adding more information to why she curses. It represents the culture of Americans which is direct and prefer simple talk as a way to express their feelings and thoughts. That is why he flouts maxim of quantity the most which is categorized as giving less and more information than needed. The comic gives less information because of the culture of prefering simple talk, and he gives more information than needed because of the culture of freedom of speech so that he can say whatever he wants to express his thoughts or feelings.

The flout of maxims which have done by both stand up comedian from Indonesia and America are proven to contribute to all types of joke technique theory by Jeannine Schwarz (2010) in order to create humor. The similarity between the uses of joke techniques that both comics employ is influenced by their ethnic background. It is supported by the research done by Nina Setyaningsih entitled Ethnic Stereotypes in Stand-Up Comedy which explores how certain ethnic are stereotyped in Stand Up Comedy Indonesia season 3 held by Kompas TV. In her research, she finds that the jokes that the comedians delivers are influenced by their ethnic background (Setyaningsih, n.d.). Even though Abdur Arsyad and Kevin Hart are from different countries, but they have the same ethnic background. Abdur comes from East side of Indonesia, and Kevin is African-American. Both of them are minority in their countries. Therefore, their way of delivering the jokes are the same in technique. It can also be supported through their same joke materials which usually discuss about their restlessness as the minority in their countries and social criticism.

\section{CONCLUSION}

Regarding to the results and discussion that has been conducted in this study, there are several conclusions that can be drawn. First, is about the flouting of cooperative principle proposed by Paul Grice. After conducting the research, the researcher comes to a conclusion that flouting maxims do not make people being uncooperative. Instead, it can be used as a technique to create humor. It is proven through the research of this study which analyzes two comics from two different countries while they flout maxims. As it is discussed in the analysis, the researcher finds that both comics are flouting all types of maxims including maxim of quantity, maxim of quality, maxim of manner, and maxim of relevance in their performances.

They flout maxim of quantity by either being uninformative or talks too much which unnecessary. The total flouts of maxim of quantity done by each comics are different, an Indonesian comic named Abdur flouts a total of 6 flouts of maxim quantity, and an American comic named Kevin Hart flouts a total of 8 flouts of maxim quantity. The flout of maxim quality is flouted by both of them by stating something that is not true and lack of evidence. Abdur flouts a total of 8 flouts of maxim quality, and Kevin flouts a total of 6 flouts of maxim quality. They also flout maxim of manner by being ambiguous or using vague language such as slang words and swear words. Abdur flouts maxim of manner 5 times during his performances, while Kevin flouts maxim of manner 7 times. Last, they flout maxim of relevance by being irrelevance. Abdur flouts maxim of relevance 6 times and Kevin flouts maxim of relevance once 
during his performances. According to the result, it shows that the most flout of maxims between two comics from two different countries is different. The most flouted maxim done by an American comic is maxim of quantity. It is in line with American culture in communication which tends to be direct and upfront at expressing their thoughts. Meanwhile, the most flouted maxim done by an Indonesian comic is maxim of quality. It is in line with Indonesianculture which tends to be indirect which make them use satiric words while criticizing others instead of frankly confronts others.

The flout of maxims which have done by both stand up comedian from Indonesia and America are proven to contribute to joke technique in order to arouse laughter. Throughout their flouting maxims, an Indonesian and an American comics are employing all types of joke technique consist of paralanguage, ridicule, satire, and politeness strategy. Through the flouts of maxim which have been done by Abdur, it is concluded that he has applied all types of joke techniques including paralanguage, ridicule, satire, and politeness strategy. Abdur employs 2 paralanguage techniques which create hostility and incongruity types of humor. He employs 9 ridicule of joke techniques which create incongruity and hostility types of humor. Then he employs 8 satire techniques of joke which create incongruity, hostility and release theories of humor. Also, he employs 1 politeness strategy which creates hostility type of humor and 1 negative politeness strategy which creates incongruity type of humor. As for an American comic named Kevin Hart, he employs 2 paralanguage techniques which create incongruity type of humor, 7 ridicule which create incongruity and hostility types of humor, 2 satires which creates release type of humor and 3 positive politeness strategies which creates incongruity type of humor. The similarity between the uses of joke techniques that both comics employ through their flout of maxims is influenced by their ethnic background. Even though they have different nationalities, however they have the same ethnic background. They are both come from the minority in their countries. That is why their techniques of joke telling are the same. Further research is hoped to explore more aspects of cooperative principles relation to create humor and also the contribution of joke techniques. Moreover, it is expected to develop new interesting finding regarding with the use of maxims among more difference countries.

\section{REFERENCES}

Abdurrahim Arsyad. (n.d.). Wikipedia. https://id.m.wikipedia.org/wiki/Abdurrahim $\underline{\text { Arsyad }}$

Amianna, J., \& Putranti, A. (2017). Humorous Situations Created by Violations and Floutings of Conversational Maxims in a Situation Comedy Entitled How I Met Your Mother. Journal of Language and Literature, 17(1).

Andresen, N. (2013). Flouting the maxims in comedy: An analysis of flouting in the comedy series Community, 29.

Attardo, S. (1990). The Violation of Grice' s Maxims in Jokes Author ( s ): Salvatore Attardo Proceedings of the Sixteenth Annual Meeting of the Berkeley Linguistics, 355-362.

Choiri, M. (2014). Humor in Reggy Hasibuan's stand-up Comedy Show Through Illocutionary Acts. Languagae Horizon, 2, 1-7.

Creswell W. John. (2009). Research Design (Third Edit). SAGE Publications, Inc. 
Jorfi, L., \& Dowlatabadi, H. (2015). Violating and Flouting of the Four Gricean Cooperative Maxims in Friends the American TV Series, (August), 364-371.

Kakabadse, N. (2007). Low- and High-Context Communication Patterns : Towards Mapping Cross-Cultural Encounters, 2-25.

Kevin Hart | Biography. (n.d). Biography. https://www.biography.com/.amp/ performer/kevin-hart

Kevin Hart. (n.d.). Wikipedia. https://id.m.wikipedia.org/wiki/Kevin_Hart

Lesmana, M. (2017). The Aspect of Ridicule in Indonesian Humor, 22(8), 51-55. https://doi.org/10.9790/0837-2208085155

Marshall. (2006). Data Collection Methods (pp. 97-150).

Miles, B. M., Huberman, M. A., \& Saldana, J. (2014). Qualitative Data Analysis (Third). SAGE Publications, Inc.

Nelson, G. L., Al, M., \& El, W. (2002). Directness vs . indirectness : Egyptian Arabic and US English communication style, 26, 39-57.

Pan, W. (2012). Linguistic Basis of Humor In Uses of Grice' s Cooperative Principle. International Journal of Applied Linguistics \& English Literature, 1(6), 20-25. https://doi.org/10.7575/ijalel.v.1n.6p.20

Rolesta, I. (2016). Implicature Analysis on Stand Up Comedy Indo Malang. Maulana Malik Ibrahim State Islamic University.

Safaudin. (2016). THE FLOUTING MAXIMS OF HUMOROUS LYING IN “ HOW I MET YOUR MOTHER ” TV SERIES. Language Horizon, 4, 23-34.

Saragi, Y. M. (n.d.). Flouting Maxims in Conversational Implicature in The Ellen Degeneres Talk Show, 100-105.

Schwarz, J. (2010). Linguistic Aspect of Verbal Humor.

Ulliyadhi, A., Raharja, S., Training, T., \& Faculty, E. (2015). ANALYSIS ON MAXIM OF COOPERATIVE PRINCIPLE VIOLATION BY DODIT MULYANTO IN STAND UP COMEDY INDONESIA SEASON 4 A Graduating Paper.

Understanding American Jokes.(2015, April 1). Columbia West College. https://www.columbiawestcollege.edu/2015/04/01/understanding-americanjokes/

Wening, L. (2017). AN ANALYSIS OF HUMOROUS CONVERSATIONS BASED ON VIOLATING AND FLOUTING OF GRICEAN CONVERSATIONAL MAXIMS IN SITUATIONAL COMEDY FRIENDS SEASON 9. Sanata Dharma University Yogyakarta.

Yamazaki, T. (2010). Conversational Implicature in Stand-up Comedies.

Yule, G. (1996). Pragmatics. Oxford University Press. 